\title{
THE WRITE RULES
}

\section{Character development.}

\section{BY FREYA MORRIS}

$\mathrm{N}$ ari stared at the brass knob. She had already tried to open the wooden door by flicking her head to one side, but it didn't work. She went through troubleshooting but found nothing; according to the system, the door wasn't there. She'd heard about lost doors: forgotten, not converted, hiding some unknown treasure. A smile filled her cheeks. Grasping the cold handle, she rattled and pushed against it until the door finally opened. The room inside glowed. Not the fluorescent white she was used to, but a dull, dim brown-yellow, filled with shadows. A familiar but forgotten smell submerged her, reminiscent of a damp cave.

An old man sat at a desk, surrounded by cream-coloured, wafer-thin piles. Wrinkles entrenched his skin like cracked soil. He looked up at her with bold eyes. A cottonwhite beard framed his open mouth. The white light behind her bleached his face. His hand hung in the air, frozen in a pinching motion that Nari hadn't seen before, his fingers arranged like a tulip, gripping a tubular black stick.

Nari pressed her tongue on the inside of her cheek, activating her screen. A translucent menu rose in front of her. She selected the camera with her eyes, zoomed in on his hand and winked, taking the picture. She flicked the frozen image onto the Internet and cross-referenced it. Nothing matched.

The screen went blank. Then a single word appeared: writing.

Her heart pounded against her ribs. Her tongue stumbled around in her mouth in a bid to turn it off. But she was too late. They would have seen it too. And they would soon be on their way.

"I’m so sorry," she blurted. "I didn't know what it was."

The old man put his head into his hands and then looked back up at her. "Quick, come here."

"What? Why?"

"We have about 20 minutes," he said, rearranging some white sheets in front of him. "I'm going to teach you how to write."

"Why?"

"For the same reason we still walk." With his palms on the table, he heaved himself up and shuffled towards her.

"But ... but it's illegal for a reason."

"Yes, but is it the right one?"

"Well it saves trees ... somehow. And the planet."

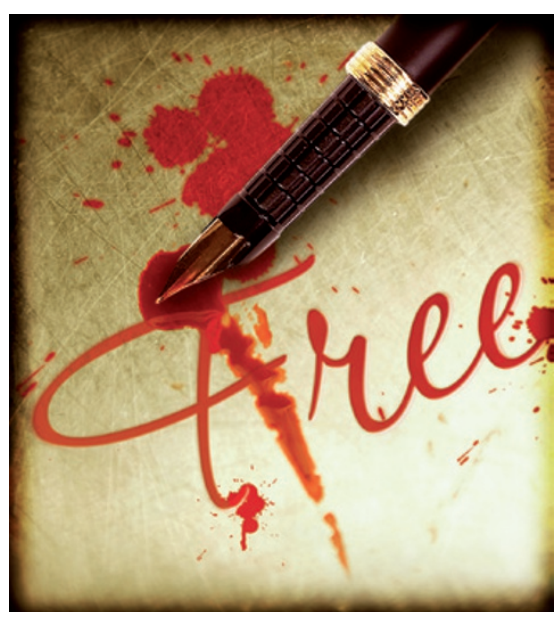

He laughed, a sound like sandpaper on wood. Nari wasn't sure how it saved trees and the planet. It was something she had been told by her parents when she was a child. Everyone was taught this. You would be punished if you ever questioned it. Punished, even if you tried to draw a single line in the sand.

“They are good aren't they?" He pointed his index finger up, holding her gaze. "But to write, is to be free."

She shook her head. "But dictation is free too."

"My dear, the cost is not tangible. When you commit a thought, dictate it, it's monitored, it's used. Even if you don't save it, they do. It's like a firework, leaving trails of light in the system. Writing was banned because it couldn't be controlled. It can't be traced. Don't you see? Writing is free, it's art, it's uncensored, you don't need a screen or a piece of software." His eyes were alight, sparkling.

"But if it's not on the system then you can't do anything with it. No one would see it. What's the point?"

"What's the point?!" He sniffed. "You'll see. Now, look, we don't have much time."

He pulled her around the desk, sat her down and placed the tubular stick in her hand.

"What's this?"

"It's charcoal."

With his leathery fingers he moulded her hand around it and pressed it down onto the white sheet in front of her.

\section{$\rightarrow$ NATURE.COM}

Follow Futures on

Facebook at:

go.nature.com/mtoodm

$$
\begin{aligned}
& \text { "Is this ... pa..." } \\
& \text { "Paper, yes. Now, }
\end{aligned}
$$
keep these three fingers here in place and push down."
Guided by the old man, Nari dragged a straight line across the page. The vibrations soared up through the stick into her fingers and up her skin.

"Good. Good. Now I want you to write your name."

"But it keeps slipping."

The old man plucked the charcoal from her hand. His fingers danced over the white sheet, marking out a word: 'John'.

"That's my name."

"Really? Jo-han"

"John."

"I've never heard that name before."

"I come from a long line of traditionalists." He smiled.

Nari grinned back. She closed her eyes and pictured her name. First, she dragged out a squiggly and large ' $N$ ', followed by a smaller 'a', which was the hardest, and then an ' $r$ ' and an 'i'. She lifted her hand up to see her name carved in squiggles on the pure white sheet.

"I did it!" She laughed. "I did it. It's beautiful."

It was as if she had been cemented; as if she suddenly existed. To see it tangibly, like that. She traced her name with her finger, stroking it carefully. She could see her curly hair in the 'a', her ambitions in the 'N' far overshadowing the rest, and the watchful ' $\mathrm{i}$ ' of her father, alien and out of place.

"Can I do pictures like this?"

"Of course. Before screens, art was done by hand. It was skill, not concept."

"But what if I get caught?"

He winked at her. "It'll be worth it."

There was a loud bang. Nari leapt from her chair, throwing the stick aside. The light in the room had dimmed; a shadow stood in the doorway. In slow motion, the shadow came towards them and grabbed John's arm.

"You are partaking in an illegal activity..."

"Me? No. I wouldn't dare."

"Writing is an illegal activity, punishable by death."

"He wasn't doing anything, were you?" Nari cried, campaigning for John's words.

He leaned close to her ear. "Better to be free in death, than imprisoned in life."

He lifted up his palms, marked with black smudges, in surrender, and smiled as he was led from the room, which moments before hadn't existed.

Freya Morris is a communications officer at the University of Bristol, UK, who by night dreams of being a scientist. This involves sneaking into lectures and delving into Nature. 